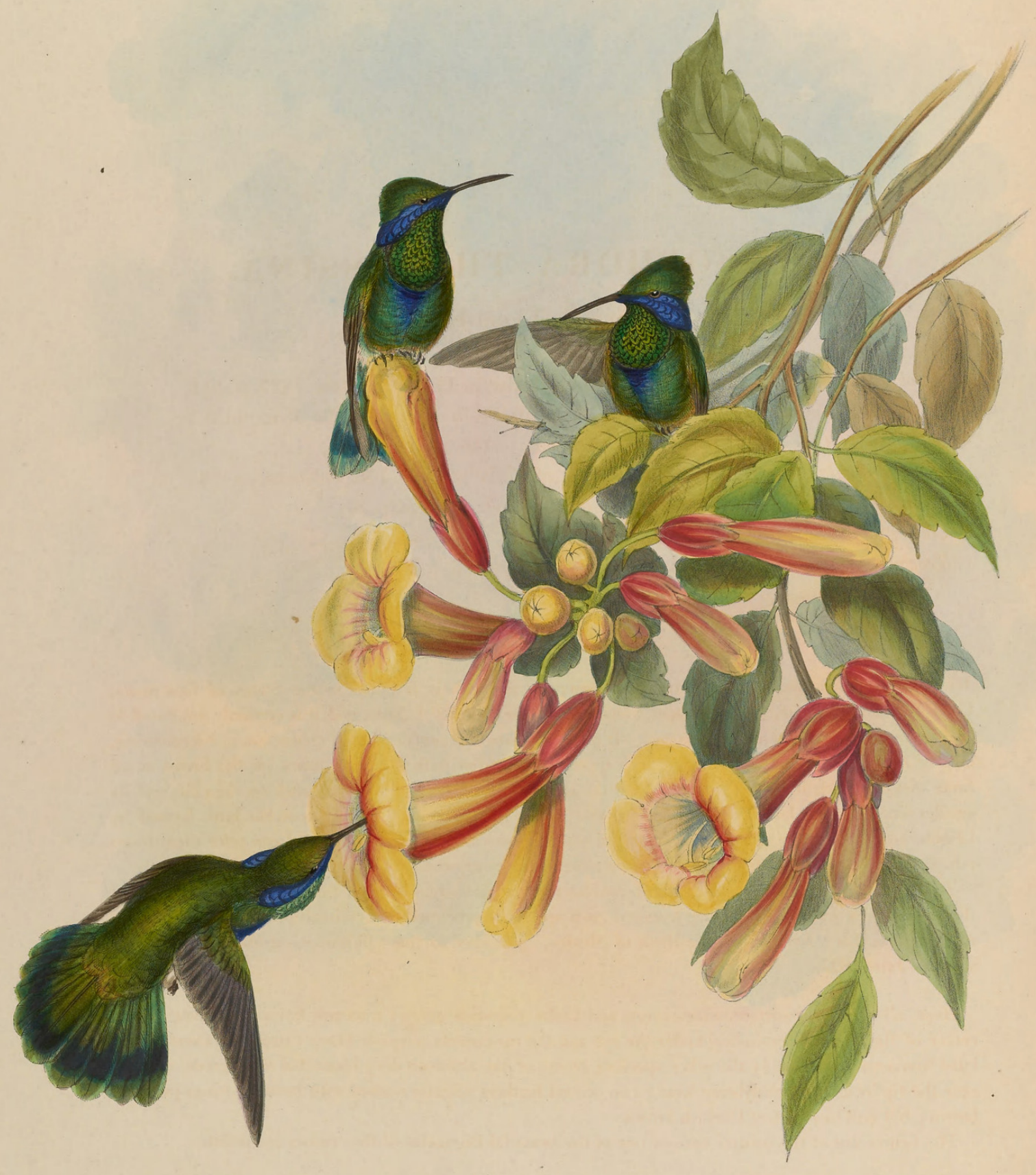




\section{PETASOPHORA THALASSINA.}

\section{Mexican Violet-Ear.}

Trochilus thalassinus, Swains. Syn. Birds of Mexico in Phil. Mag., June 1827, p. 441.

Ornismya Anais, Less. Hist. Nat. des Col., p. 104.-Ib. Supp. des Ois. Mou., pl. 3 ?

Ramphodon Anais, Less. Hist. Nat. des Troch., p. 148. pl. 56 ?

Polytmus thalassinus, Gray and Mitch. Gen. of Birds, vol. i. p. 108, Polytmus, sp. 26.

Petasophora thalassinus, Gould in Proc. of Zool. Soc., Part xv. p. 8.

Colibri thalassinus, Bonap. Consp. Gen. Av., p. 69, Colibri, sp. 2.

Trochilus Anais, Jard. Nat. Lib. Humming Birds, vol. ii. p. 2?

Mexico may claim this species as strictly its own; for although it is found in the States of Guatemala, Costa Rica and Veragua, Mexico proper would seem to be its chief habitat, and it is certainly not found to the southward of the Isthmus of Panama. It presents a singular combination of characters in its colouring, uniting $P$. cyanotus with $P$. Anais, but it is quite distinct from both; the blue mark on the breast at all times distinguishing it from the former, and the almost total absence of the blue mark on the chin, and its smaller size, from the latter. It will be seen that I have thought it likely that two of the birds figured by Lesson, under the name of Anais, are identical with the present species, and indeed I can refer them to no other; at the same time his figures are by no means correct representations.

To Mr. Swainson pertains the credit of characterizing this bird as distinct from all the other species of the family then known, he having assigned to a specimen procured at Temiscaltipec the appellation of thalassinus in his "Synopsis of the Birds of Mexico," published in the "Philosophical Magazine" as long since as June 1827.

Head, all the upper surface, wing-coverts and flanks yellowish green; a narrow line commencing on the centre of the chin and extending under the eye and the ear-coverts purplish blue; throat and chest tessellated luminous green, as in the other species; centre of the abdomen deep blue; tail deep green, crossed near the tip by a broad chalybeate band; two central feathers slightly washed with bronze; wings purplish brown; bill dull black; feet blackish brown.

The figures are of the natural size, on one of the beautiful Bignonias of the country it inhabits. 


\section{$2 \mathrm{BHL}$ Biodiversity Heritage Library}

Gould, John. 1858. "Petasophora thalassina, Mexican Violet-Ear. [PI. 227]." $A$ monograph of the Trochilidae, or family of humming-birds 4, https://doi.org/10.5962/p.317036.

View This Item Online: https://www.biodiversitylibrary.org/item/108334

DOI: https://doi.org/10.5962/p.317036

Permalink: https://www.biodiversitylibrary.org/partpdf/317036

\section{Holding Institution}

Smithsonian Libraries

\section{Sponsored by}

Smithsonian Institution Libraries

\section{Copyright \& Reuse}

Copyright Status: NOT_IN_COPYRIGHT

This document was created from content at the Biodiversity Heritage Library, the world's largest open access digital library for biodiversity literature and archives. Visit BHL at https://www.biodiversitylibrary.org. 